УДК 159.923

DOI https://doi.org/10.51547/ppp.dp.ua/2021.6.13

Казакова Слизавета Сергіївна,

ад'юнкт ад'юнктури навчально-наукової лабораторії

екстремальної та кризової психології науково-дослідного центру

Національного університету цивільного захисту України

ORCID ID: 0000-0002-0135-0876

\title{
ОСОБЛИВОСТІ КОПІНГ-СТРАТЕГІЙ У ЛЮДЕЙ ІЗ РІЗНИМ СТАВЛЕННЯМ ДО ВІРУСУ COVID-19
}

\section{FEATURES OF COPY STRATEGIES IN PEOPLE WITH DIFFERENT ATTITUDES TOWARDS COVID-19 VIRUS}

У статті розглядається актуальна проблема для всього всесвіту, а саме: зіткнення суспільства з умовами карантинних обмежень внаслідок пандемії COVID-19. Ситуація, яка торкнулась абсолютно кожної людини, зумовила необхідність вивчення психологічних особливостей способів подолання та вирімення особистістю проблемних питань, щзо виникли внаслідок пандемії COVID-19.

У статті, метою якої є вивчення особливостей копінг-стратегій у населення щзодо ситуації навколо захворюваності на COVID-19, надається характеристика основних копінг-механізмів та копінг-стратегій, завдяки яким чоловіки та жінки справляються зі стресом та стресовими ситуачіями; пропонується розгляд взаємозв'язку вибору чоловіками та жінками тих чи інших копінгів залежно від ставлення до ситуачії навколо пандемії.

Результати показали, щчо, незважаючи на те, що карантинні обмеження тривають вже другий рік, $є$ люди, які вважають коронавірусну хворобу надуманою загрозою для життя та що ї̈ значення перебільшене; є люди, які вважають COVID-19 реальною загрозою для населення, але лише для тих, у кого слабкий імунітет; ті, хто вважає загрозу COVID-19 дуже небезпечною, і лише деякі особистості з опитуваних сприймають COVID-19 як реальну загрозу для всього населення та вважають, що слід дотримуватися карантинних обмежень.

У дослідженні показано, щзо чоловіки більш емоційно дестабілізовані у вирішенні складних питань, пов'язаних із поширенням коронавірусної хвороби COVID-19, аніж жінки.

Результати респондентів щодо копінг-механізмів та способів подолання труднощів показали, що в межах актуальної ситуації навколо пандемії COVID-19 частіше використовуються такі копінг-механізми: «конфронтаційний», «втеча-уникнення», «планування вирішення проблеми», «позитивна переоцінка». При цьвому найменш виразними в ияих умовах є такі, як «самоконтроль», «дистанціювання» та «пошук соціальної підтримки».

Показано, щзо чоловіки та жінки здебільшого вибирають різні копінг-механізми для подолання стресових ситуацій у межах карантинних обмежень, але і є ті копінг-механізми, які обидві групи досліджених використовують однаково.

Ключові слова: пандемія; COVID-19;психічний стан; карантин; копінг-стратегї; копінг-механізми; копінг.

This article examines the urgent problem for the entire world, namely the confrontation of society with the conditions of quarantine restrictions as a result of the COVID-19 pandemic. The situation, which affected absolutely every person, necessitated the study of psychological features of ways to manage and solve the individual's problematic issues that arose as a result of the COVID-19 pandemic.

The aim of this article is to study the specifics of coping strategies in the population in relation to the situation with COVID-19 infection. The article describes the main coping mechanisms and coping strategies that help men and women to cope with stress and stressful situations; The study of the relationship between men's and women's use of certain coping strategies depending on their attitude to the situation around the pandemic.

The results showed that despite the fact that the term of quarantine restrictions has been in force for two years, there are people who consider coronavirus disease as a contrived threat to life and have increased its importance; There are people who consider COVID-19 a real threat to the population, but only for those with weak immunity; Those who consider the threat of COVID-19 to be very dangerous and only some individuals among those surveyed perceive COVID-19 as a real threat to the entire population and are worried that quarantine restrictions should be observed.

The study showed that men are more emotionally destabilized in resolving complex issues related to the spread of the COVID-19 coronavirus disease than women.

The results of respondents for coping mechanisms showed that within the framework of the current situation around the COVID-19 pandemic the following coping mechanisms are used more often: "confrontational", "leakage-avoidance", 
"problem-solving planning”, "positive reevaluation". At the same time, "self-control”, "distancing” and "seeking social support" are the most significant in these conditions.

It was shown that men and women mostly choose different coping mechanisms to cope with stressful situations within quarantine restrictions, but there are also those coping mechanisms that are used equally by both groups of respondents.

Key words: pandemic, COVID-19, mental state; quarantine; coping strategies; coping mechanisms; coping.

Вступ. Ситуація з поширенням вірусу COVID-19 внесла зміни в усі галузі нашого життя: у багатьох країнах зупинено роботу підприємств, припинено роботу навчальних закладів, скасовано громадські заходи, введено обмежений режим переміщень, закрито на карантин цілі міста. Вулиці великих міст стали порожніми, більшість галузей промисловості призупинилася на невизначений термін. Багато людей за короткий час опинилися в ситуації раптової втрати роботи, краху бізнесу та фінансової нестабільності [1]. Вже другий рік триває пандемія, а 3 нею карантинні обмеження, з якими особистості треба справлятися.

За добу 27 жовтня в Україні зафіксовано 26071 нових підтверджених випадків коронавірусної хвороби COVID-19 (з них 1830 дітей, 477 медпрацівників), при цьому за добу до лікарень було ушпиталено 5366 пацієнтів із COVID-19. Подолати захворювання змогли 10006 людей. 94\% госпіталізованих із COVID-19 минулого тижня невакциновані, - наголосили в МО3 [11].

За весь час пандемії в Україні на COVID-19 захворіло 2851804 людини, одужало 2411711 пацієнтів. При цьому в країні зафіксовано 66204 летальних випадки від захворювання та проведено 14232081 ПЛР-тестування. Водночас у Міністерстві заявили про черговий рекорд із кількості проведених щеплень. За даними МОЗ, протягом доби від COVID-19 вакцинувалися 291985 людей. При цьому одну дозу щеплення отримали 212684 людини, повністю імунізовано 79301 людину [11].

Усі ці обставини спричиняють страхи, підвищення тривожності, посилення стресових реакцій, які можуть негативно позначатись на здоров'ї населення. Так, відомо, що маркерами стресового стану є занепокоєння, депресивний настрій, роздратування, порушення сну, зміни апетиту, головний біль, біль у грудях, задишка, біль у тілі, запаморочення тощо [16].

Аналіз останніх досліджень і публікацій. Під час карантинних заходів психічний стан населення значно погіршився [4]. Нинішні реалії стають причиною загальної депресії населення, та, незважаючи на пом'якшення обмежень, чимало людей відчувають стрес та тривогу через необхідність повертатися в офіс, страх їхати в громадському транспорті. Крім того, більшість людей стикнулася $з$ дезадаптацією - це порушення здат- ності пристосування до умов існування, насамперед втрата пристосування до умов соціального середовища [1].

Дослідження щодо того, як психологічно позначається і позначиться в майбутньому пандемія та карантин на людському житті, тривають. Однак вже частково представлена низка цікавих даних із різних куточків світу про те, як саме людство реагує на COVID-19 [16; 25; 26]. Зазначено, що кожна культурна схема (національність) має свої особливості реагування на кризові ситуації, які залежать і від рівня соціально-економічного розвитку, і від зрілості особистості. Частково це пояснюється різною якістю життя та рівнем освіти [1].

Результати зарубіжних досліджень продемонстрували глибокий і широкий спектр психологічних наслідків, до яких може призвести спалах COVID-19: поява нових психіатричних симптомів в осіб, які не мають психічних захворювань; погіршення стану тих, хто вже страждає на такі захворювання; дистрес у доглядальників за пацієнтами 3 психічними та соматичними недугами. До того ж спалах коронавірусної хвороби передбачувано спричиняє і суспільні психологічні реакції, такі як напруження, тривога і страх, втрата орієнтирів і планів на майбутнє, що може теж призводити до гострої реакції на стрес, депресії, інших емоційних розладів i, як наслідок, до зростання аутоагресивних дій аж до суїцидальних. Спектр зумовлених пандемією психічних порушень може коливатися від депресії, тривоги, панічних нападів, соматичних симптомів та психозу до навіть суїциду [21; 23; 24].

Стрес, викликаний важливими життєвими подіями, відіграє ключову роль у виникненні депресивних симптомів, які часто пропорційні масштабу подій i включають міжособистісні втрати або соціальне неприйняття. Зрештою, глобальні події, такі як стихійні лиха, технологічні катастрофи та терористичні акти, серйозно збільшують ризик депресії серед великих груп населення, що потребує конкретних та широкомасштабних втручань для пом'якшення їхнього впливу на психічне здоров'я [23-26].

Пандемія COVID-19 зумовила побоювання в людини щодо ризиків для власного здоров'я та здоров'я своїх близьких та ії довгострокових економічних наслідків [10; 20; 24; 25]. Крім того, за 
деякими свідченнями, карантинні заходи можуть посилювати симптоми гострого та посттравматичного стресу, депресії та гніву [24].

В умовах динамічного розвитку пандемії COVID-19 перед людиною постають нові життєві труднощі, нові проблеми, задачі, котрі дають привід для конфліктів, кризових ситуацій. Від якості їх подолання суттєво буде залежати вектор розвитку, стан психосоматичного здоров'я і соціальна адаптація людини [2; 3; 5-7].

Здатність долати труднощі в психологічній літературі описують за допомогою терміна «копінг» (від англійського “соре" - впоратися, подолати) [7]. Поняття об'єднує когнітивні, емоційні та поведінкові стратегії, які використовуються особистістю, щоб впоратися із запитами буденного життя. У психології копінг можна розуміти як розширення (збільшення) свідомого зусилля задля вирішення особистих та міжособистих проблем i намагання опанувати, мінімізувати або переносити стрес чи конфлікт. Ефективність копінгових зусиль (копінгу) залежить здебільшого від типу стресу та індивідуальних особливостей кожної окремої людини і обставин [17].

Теоретичний аналіз психологічної літератури дозволив нам визначити, що копінг-стратегії розглядають у рамках вивчення захисних механізмів особистості (М. Водсворт, Г. Зальтсман, Б. Компас, Дж. Конор-Сміт, П. Крамер, А. Томсен, Н. Хан), сукупності ії особистісних рис (Р. Горзух, К. Шефер) і як процес взаємодії людини з навколишнім середовищем (Б. Гунсбергер, Р. Горзух, Р. Лазарус, Б. Спілка, С. Фолькман, Р. Худ) [17]. Інші вчені, зокрема Р. Лазарус, Л. Мерфі, С.К. НартоваБочавер, вивчають прийоми подолання складних стресових ситуацій, станів, умов, які свідомо використовуються людиною [6-8]. Також наводяться дані, що особливості вибору копінг-стратегій особистістю часто пов'язані з її Я-концепцією, самооцінкою, ємпатією, віком, статевою приналежністю, умовами середовища та соціальним досвідом [5].

Вперше термін «копінг-стратегія» запропонував Л. Мерфі у 1962 р. для визначення поведінкових реакцій дитини, яка долає кризу розвитку [18]. Потім Р. Лазарус у роботі «Психологічний стрес і процес його подолання» використав термін «копінг-стратегія» для визначення усвідомлених стратегій поведінки в процесі подолання стресу і виходу з нього [19].

Дж. Кохен і Р. Лазарус, узагальнивши дані інших досліджень, виділили п'ять основних завдань копінгу:

1) мінімізація негативних впливів на особистість, підвищення можливостей відновлення;
2) пристосування, перетворення або врегулювання життєвих ситуацій;

3) впевненість у своїх силах, підтримання позитивного «образу Я»;

4) підтримання емоційної рівноваги;

5) збереження тісних зв'язків 3 іншими людьми [14].

Успішність подолання стресу безпосередньо залежить від реалізації перерахованих завдань. Поведінка людини оцінюється як успішна, якщо вона: зменшує психологічні та усуває фізіологічні прояви напруги; дає змогу відновити достресову активність; оберігає індивіда від психічного виснаження, тобто, іншими словами, запобігає дистресу [7].

Таким чином, як критерії ефективності подолання стресу висуваються такі фактори, як психічне благополуччя, зниження рівня невротизації, вразливості до стресів. Ефективність копінгу науковці пов'язують також із тривалістю позитивних наслідків та виділяють такі два види наслідків подолання стресової ситуації, як короткочасні та довготривалі ефекти [13].

Найвідомішим підходом у трактуванні копінгу нині $є$ трансакційний підхід, який розробили Р. Лазарус і С. Фолькман [14]. Вчені розглядають поняття копінгу як постійний процес взаємодії індивідом з середовищем. Згідно з цим підходом, основними елементами копінгу є частота появи відповідної ситуації, іiі первинна та вторинна когнітивні оцінки, процес подолання труднощів, а також сукупність наслідків копінгу, зокрема для фізичного, психічного здоров'я й соціального добробуту.

На думку Р. Лазаруса і С. Фолькман, існує два модуси психологічного подолання: подолання, спрямоване на розв'язання проблеми (problemfocused), або подолання, орієнтоване на зміну власних установок щодо ситуації (emotion-focused). Проблемно орієнтований копінг пов'язаний iз раціональним аналізом проблеми, побудовою плану вирішення складної ситуації і проявляється в самостійному аналізі того, що сталося, та зверненні за допомогою до інших, пошуку додаткової інформації тощо. Емоційно орієнтований модус психологічного подолання стосується емоційного реагування на ситуацію, він не супроводжується конкретними діями [18-19].

Розглядаючи копінг-стратегії, залежно від модальності, Е. Хайм пропонував виділяти поведінкові, когнітивні й емоційні стратегії. Кожна 3 них має свій ступінь адаптивних можливостей: адаптивні, відносно адаптивні й неадаптивні копінг-стратегії [8]. 
Метою статті $\epsilon$ вивчення особливостей копінгстратегій у населення щодо ситуації навколо захворюваності на COVID-19.

Методика дослідження. У нашому дослідженні взяли участь 72 особи, яких ми поділили на дві групи за статевою ознакою, що нам дало змогу визначити копінг-механізми, способи подолання труднощів у різноманітних сферах психічної діяльності чоловіків та жінок. Так, 1 група - це чоловіки (39 осіб; 2 група - жінки (33 особи). Вік респондентів - від 16 до 45 років.

Для дослідження особливостей реагування на ситуацію щодо вірусу COVID-19 та специфіки сприйняття обмежень внаслідок цього нами було проведено анкетування. Задля цього нами було розроблено авторську анкету. Поряд із цим для вивчення копінг-механізмів досліджуваних ми використали копінг-тест Лазаруса, який включає в себе 8 типів реагування в стресі: «конфронтація», «дистанціювання», «самоконтроль», «пошук соціальної підтримки», «прийняття відповідальності», «втеча-уникнення», «планування вирішення проблеми» та «позитивна переоцінка». Статистична обробка даних проводилась за допомогою програми SPSS Statistics 23 [9].

Виклад основного матеріалу. Згідно 3 відповідями на анкетування нами встановлено, що $\epsilon$ люди, які вважають коронавірусну хворобу надуманою загрозою для життя та перебільшено ії значення - 16,7\%; є люди, які вважають COVID-19 реальною загрозою для населення, але лише для тих, у кого слабкий імунітет, $-51,4 \% ; 8,3 \%$ опитуваних вважають загрозу COVID-19 дуже небезпечною; 23,6\% сприймають COVID-19 як реальну загрозу для всього населення та вважають, що варто дотримуватися карантинних обмежень.

Показано, що серед опитуваних більшість респондентів не хворіла на COVID-19, але показники на захворювання близьких людей респондентів значно вищі. Також у процесі дослідження було встановлено, що значних відмінностей за всіма типами реагування в стресі не було виявлено, окрім двох типів: «втеча-уникнення» та «позитивна переоцінка».

Отримані дані за тестом Р. Лазаруса зображені в табл. 1.

За даними «конфронтаційного» копінгу різниця між чоловіками та жінками незначна. Ця стратегія передбачає спроби вирішення проблеми за рахунок не завжди цілеспрямованої поведінкової активності, здійснення конкретних дій, спрямованих або на зміну ситуації, або відреагування негативних емоцій у зв'язку з труднощами. На нашу думку, це може свідчити про те, що ситуація, яка склалася у світі щодо пандемії, має багато невизначеності, що може призводити до використання «конфронтаційного» копінгу чоловіками і жінками в рівній значущості. Часто стратегія «конфронтації» розглядається як неадаптивна. I ми вважаємо, що це пов'язано з тим, з яким стрес-фактором зіткнулась особистість для вирішення проблеми.

Автор методики виділяє позитивні та негативні сторони копінгу. Позитивними виступають можливість активного протистояння труднощам та стресогенному впливу, а негативними - недостатня цілеспрямованість та раціональна обгрунтованість поведінки у проблемній ситуації [5].

Результати за копінгом «дистанціювання» свідчать, що різниця між досліджуваними групами також незначна (див. табл. 1). Ця стратегія передбачає спроби подолання негативних переживань у зв'язку 3 проблемою завдяки суб' єктивному зниженню іiі значущості та ступеня емоційної залученості до неї. Характерне використання інтелектуальних прийомів раціоналізації, перемикання уваги, усунення, гумору, знецінення тощо.

Таблиця 1

Показники копінг-механізмів 1 та 2 групи $(\mathrm{M} \pm \mathbf{m})$

\begin{tabular}{|c|c|c|c|c|}
\hline Назва шкал & $\begin{array}{c}\mathbf{M} \pm \mathbf{m} \\
\mathbf{I ~} \mathbf{~} \mathbf{p .}\end{array}$ & $\begin{array}{c}\mathbf{M} \pm \mathbf{m} \\
\mathbf{I I ~} \mathbf{~ \mathbf { p . }}\end{array}$ & $\mathbf{t}$ & $\mathbf{p}$ \\
\hline Конфронтаційний копінг & $7,636 \pm 3,621$ & $7,205 \pm 4,354$ & 0,4593 & - \\
\hline Дистанціювання & $8,061 \pm 4,183$ & $7,385 \pm 4,037$ & 0,694 & - \\
\hline Самоконтроль & $11,00 \pm 3,905$ & $9,897 \pm 5,16$ & 1,031 & - \\
\hline Пошук соціальної підтримки & $9,788 \pm 3,911$ & $8,487 \pm 3,516$ & 1,472 & - \\
\hline Прийняття відповідальності & $6,303 \pm 2,778$ & $5,256 \pm 2,854$ & 1,573 & - \\
\hline Втеча-уникнення & $12,061 \pm 4,956$ & $8,974 \pm 5,542$ & 2,494 & 0,05 \\
\hline $\begin{array}{c}\text { Планування вирішення } \\
\text { проблеми }\end{array}$ & $11,515 \pm 3,615$ & $10,59 \pm 4,94$ & 0,915 & - \\
\hline Позитивна переоцінка & $12,939 \pm 4,213$ & $10,128 \pm 4,868$ & 2,627 & \\
\hline
\end{tabular}


I це, ми вважаємо, дає змогу особистості не втрачати надію на те, що в найближчому майбутньому світ подолає пандемію COVID-19.

За копінгом «самоконтроль», який передбачає спроби подолання негативних переживань у зв'язку з проблемою за рахунок цілеспрямованого придушення та стримування емоцій, мінімізації їх впливу на оцінку ситуації та вибір стратегії поведінки, високий контроль поведінки, прагнення самовладання, значущих відмінностей не було виявлено (див. табл. 1). У разі виразної переваги стратегії «самоконтролю» в особистості може спостерігатися прагнення приховувати від оточення свої переживання та спонукання у зв'язку $з$ проблемною ситуацією. Часто така поведінка свідчить про страх саморозкриття, надмірну вимогливість до себе, що призводить до надконтролю поведінки.

Далі ми розглядаємо копінг «пошук соціальної підтримки», який передбачає спроби вирішення проблеми за рахунок залучення зовнішніх (соціальних) ресурсів, пошуку інформаційної, емоційної та дієвої підтримки. Характерними $€$ орієнтованість на взаємодію з іншими людьми, очікування уваги, поради, співчуття. Одна назва копінгу свідчить про недоцільність використання його досліджуваними саме через те, що хвороба поширюється через близькі контакти людей. Щоб зберегти своє здоров'я та близьких, населенню слід звести до мінімуму соціальні контакти. Також можна зазначити і важливість використання цього копінгу нині, тому що самотужки впоратись людині 3 такими обмеженнями у всьому: відвідування робочого міста, звичайні прогулянки у парку, відвідування кафе та ресторанів, театрів, кіно, тощо - це велике випробування для кожного, і зовнішня підтримка вкрай необхідна для подолання переживань, викликаних коронавірусною хворобою.

За результатами стратегії «прийняття відповідальності», яка передбачає визнання суб'єктом своєї ролі у виникненні проблеми та відповідальності за ії вирішення, у низці випадків із виразним компонентом самокритики та самозвинувачення також немає відмінностей між чоловіками та жінками (див. табл. 1). У разі помірного використання ця стратегія відбиває прагнення особистості розуміння залежності між власними діями та його наслідками, готовність аналізувати свою поведінку, шукати причини актуальних труднощів в особистих недоліках і помилках. Разом із тим виразність цієї стратегії в поведінці може призводити до невиправданої самокритики, переживання почуття провини та незадоволеності собою.
Ми можемо припустити, що розгляданий копінг не має великого попиту в досліджуваних тому, що через невизначеність навколо ситуації пандемії COVID-19 важко приймати важливі рішення та брати за них відповідальність.

За копінгом «втеча-уникнення» було виявлено значні відмінності між групами $(\mathrm{t}=2,494$, $\mathrm{p}<0,05)$. Дані представлені у табл. 1. Стратегія «втечі-уникнення» передбачає спроби подолання особистістю негативних переживань у зв'язку 3 труднощами за рахунок реагування на кшталт ухилення: заперечення проблеми, фантазування, невиправданих очікувань, відволікання тощо. У разі виразної переваги стратегії уникнення можуть спостерігатися неконструктивні форми поведінки у стресових ситуаціях: заперечення чи повне ігнорування проблеми, ухилення від відповідальності та дій із розв'язання труднощів, пасивність, нетерпіння, спалахи роздратування, занурення у фантазії, переїдання, вживання алкоголю 3 метою зниження болісного емоційного напруження. На нашу думку, цей копінг найяскравіше демонструє психоемоційний стан особистості нашого часу. Так, нами було встановлено раніше, що чим драматичніше людина сприймає загрозу «зустрітись» із вірусом, чим важче ій даються всі обмеження внаслідок цього, тим більш радикальними можуть бути іiі рішення щодо способу свого життя зокрема та світогляду взагалі. Своєю чергою напруження, страх та виснаження можна назвати постійними супутниками психоемоційного стану людини, яка переживає ситуації навколо поширення вірусу COVID-19 [10].

Далі представлені результати за копінгом «планування вирішення проблеми». Він передбачає спроби подолання проблеми за рахунок цілеспрямованого аналізу ситуації та можливих варіантів поведінки, вироблення стратегії вирішення проблеми, планування власних дій 3 урахуванням об'єктивних умов, минулого досвіду та наявних ресурсів. Стратегія розглядається більшістю дослідників як адаптивна, що сприяе конструктивному вирішенню труднощів. На нашу думку, використовувати цей копінг під час вирішення поставленої проблеми дещо важче, тому що брак інформації щодо продовження карантинних обмежень, появи і поширення вірусу, його реального впливу на здоров'я людини свідчать про неможливість планувати своє майбутнє та взагалі висловлювати якісь припущення та плани щодо завершення пандемії COVID-19.

Нами була виявлена значна різниця між чоловіками та жінками за копінгом «позитивна переоцінка» $(\mathrm{t}=2,627, \mathrm{p}<0,05)$. Стратегія «позитив- 
ної переоцінки» передбачає спроби подолання негативних переживань у зв'язку з проблемою за рахунок іiі позитивного переосмислення, розгляд iї як стимулу для особистісного зростання. Характерна орієнтованість на надособистісне, філософське осмислення проблемної ситуації, включення ïx у ширший контекст роботи особистості над саморозвитком. Серед опитуваних $\epsilon$ такі особистості, які вважають загрозу вірусу надуманою або реальною загрозою лише для тих, хто має слабкий імунітет, і саме тому, на нашу думку, вони можуть використовувати цей копінг для вирішення проблемної ситуації.

Згідно 3 тестом Р. Лазаруса в адаптації Л. Вассермана, також можна визначити ступінь переваги для випробуваного стратегії подолання стресу. Існують три ступеня: рідкісне використання відповідної стратегії; помірне використання відповідної стратегії; виражена перевага відповідної стратегії [2].

У нашому дослідженні ми розглядали виключно виражену перевагу стратегій, тому що нас цікавили ті показники, які на цьому етапі життя особистість використовує в процесі вирішення проблем, викликаних пандемією COVID-19 та карантинними обмеженнями. Отримані дані відображено на рис. 1 (діаграма).

Так, було встановлено, що «конфронтаційний» копінг у чоловіків має виражену перевагу у $28,00 \%$ опитуваних, тоді як у жінок цей показник менший $-15,15 \%$.

За «дистанціюванням» чоловіки мають $15,38 \%$ вираженої переваги, а жінки своєю чергою мають вищий відсоток майже у два рази $-27,27 \%$. Це можна розуміти так, що жінки більш емоційні, тому їхні показники вищі, а чоловіки мають низький відсоток, тому що емоційно виключені із ситуації, знижують iï суб'єктивну значущість із метою подолання негативних переживань (відмовляються це сприймати занадто серйозно).

Значна різниця існує за копінгом «втеча-уникнення». Жінки мають виражену перевагу цього копінгу у 42,42\% опитуваних, чоловіки ж $20,51 \%$ виразності. Ми можемо припустити, що такі показники у жінок через те, що вони частіше звертаються до емоційно орієнтованого й уникаючого подолання стресової ситуації, яка викликана пандемією COVID-19, тобто жінки шукають достовірну інформацію, соціальну підтримку, але націлені на втечу або уникнення від проблеми.

«Самоконтроль» на високому рівні використання, представлений у найменшій кількості досліджуваних, передбачає зусилля 3 регулювання почуттів і дій. Серед опитуваних виявлено лише 4 людини, де 3 чоловіка та 1 жінка, які мають високий рівень використання цього копінгу. Ця стратегія припускає спроби подолання негативних переживань у зв'язку з проблемою за рахунок цілеспрямованого придушення і стримування емоцій, мінімізації їх впливу на оцінку ситуації та вибір стратегії поведінки, високий контроль поведінки. Саме тому, на нашу думку, показник такий низький. Пандемія дестабілізувала психоемоційно майже кожного, про це ми згадували в наших попередніх працях [10].

Результати дослідження показали, що копінгстратегія «планування вирішення проблеми» у жінок виражена на $33,33 \%$, тоді як у чоловіків 20,51\%, що належить до проблемно орієнтованого

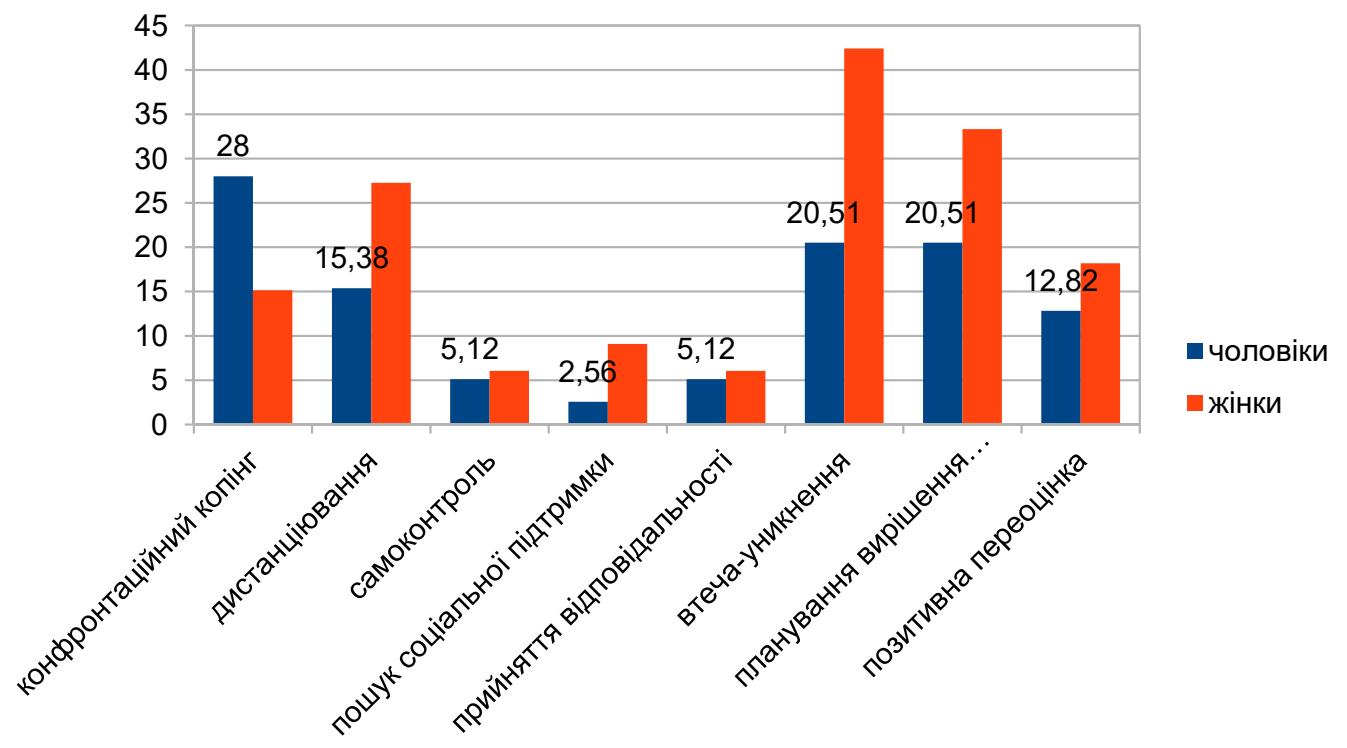

Рис. 1. Відсотковий розподіл ступеня переваги копінг-механізмів обох груп 
копінгу. Як показує практика, це найефективніша стратегія подолання проблемних ситуацій, оскільки спрямована на активну зміну ситуації та іiї конструктивне вирішення. Такий підхід до стресових моментів включає таку функцію мислення, як аналітика. Це відкриває пошук можливих варіантів поведінки. Вибір цієї стратегії виражає активну поведінкову реакцію людини, оскільки це уможливлює цілеспрямоване і планомірне вирішення проблемної ситуації. Але у зв'язку з тим, що ситуація навколо пандемії має багато запитань, невирішених проблем, карантинних обмежень, неясність у часовому просторі, показники опитуваних мають досить низькій рівень виразності та використання.

Копінг-стратегія «позитивна переоцінка», яка спрямована на переоцінку негативних переживань, розгляд їх як ресурс для особистого зростання. У 18,18\% жінок має високий рівень виразності, у чоловіків лише $12,82 \%$. Використання цієї копінг-стратегії включає ймовірність недооцінки особистістю можливостей дієвого вирішення проблемної ситуації.

Висновки. Встановлено, що чоловіки, на відміну від жінок, мають більший показник за такими копінг-механізмами, як «втеча-уникнення» та «позитивна переоцінка». «Втеча-уникнення» характеризує чоловіків у стресовій ситуації як особистість, спрямовану на поведінкові зусилля, які спрямовані на втечу або уникнення від проблеми.

За стратегією «позитивна переоцінка» чоловіки спрямовують зусилля на створення пози- тивного значення 3 фокусуванням на зростанні власної особистості. Стратегія включає також релігійний вимір.

Такі дані свідчать про те, що чоловіки більш емоційно дестабілізовані у вирішенні складних питань, пов'язаних із поширенням коронавірусної хвороби COVID-19.

Показники респондентів за копінг-механізмами та способами подолання труднощів показали, що залежно від віку, статі та того, як впливає актуальна ситуація навколо пандемії COVID-19, частіше використовуються такі копінг-механізми: «конфронтаційний», «втеча-уникнення», «планування вирішення проблеми», «позитивна переоцінка». Можна виділити й менш виражені - «самоконтроль», «дистанціювання» та «пошук соціальної підтримки».

На нашу думку, це свідчить про те, що карантинні обмеження, невизначеність у часових рамках, продовження цих обмежень, їх посилення або послаблення не дають змоги населенню критично осмислювати своє майбутнє, перспективи та плани.

Перспективою подальшого дослідження $\epsilon$ питання, пов'язані з порівнянням копінг-механізмів у різних вікових груп, груп людей, які перебували в різних стресових ситуаціях, і розробка системи психологічної профілактики негативних психічних станів та емоційного вигорання серед населення, особливо в періоди загострення ситуації із захворюваністю на COVID-19.

\section{СПИСОК ЛІТЕРАТУРИ:}

1. Быховец Ю. В., Дан М. В., Никитина Д. А. Международный опыт исследований и практических рекомендаций населению в период пандемии коронавируса. URL: http://www.ipras.ru/cntnt/rus/institut_p/covid-19/ kommentarii-eksp/bih.html

2. Вассерман Л. И., Иовлев Б. В., Исаева Р. Е. и др. Методика для психологической диагностики способов совладания со стрессовыми и проблемными для личности ситуациями : пособие для врачей и медицинских психологов. Санкт-Петербург : Психоневрологический институт им. В. М. Бехтерева, 2008.

3. Выготский Л. С. Исторический смысл психологического кризиса. Собрание соч. : в 6 т. Т. 1. Москва : Педагогика, 1982. С. 291-436.

4. Вплив пандемії COVID-19 та карантину на психологічний стан людини. URL: https:/gatne-rada.gov.ua/ covid19-doslidzhennyavplivu-15-43-44-23-07-2020/

5. Вдовиченко А. В. Особливості копінг-поведінки особистості у життєвих та професійних ситуаціях. Вісник Чернігівського начіонального педагогічного університету. Серія : Психологічні науки. 2013. № 114. С. 17-20.

6. Нартова-Бочавер С. К. “Сорingbehaviour” в системе понятий психологии личности. Психологический журнал. 1994. Т. 15. № 1. С. 3-18

7. Лазарус Р. С. Теория стресса и психофизиологические исследования. Эмоциональный стресс / под ред. Л. Лева. Ленинград, 1970.

8. Малкина-Пых И. Г. Стратегии поведения при стрессе. Московский психологическийжурнал. 2007. № 12. С. 15-25

9. Наследов A. H31 SPSS 19: профессиональный статистический анализ данных. Санкт-Петербург : Питер, 2011. 400 с.: ил.

10. Оніщенко Н. В., Казакова Є. С. Психологічні особливості сприйняття ситуації навколо пандемії COVID-19. Проблеми екстремальної та кризової психології. 2021. № 2(2). С. 6-18.

11. Понад 26 тисяч випадків за добу. В Україні зростає кількість хворих на COVID-19. URL: https:/suspilne. media/175643-ponad-26-tisac-vipadkiv-za-dobu-v-ukraini-zrostae-kilkist-hvorih-na-covid-19/ 
12. Психология развития человека. Москва : Смысл; Эксмо, 2005. 1136 с.

13. Фрейд 3. Введение в психоанализ: Лекции. Москва : Наука, 1989. 456 с. (Серия «Классики науки»).

14. Хорни К. Невротическая личность нашего времени. Самоанализ. Москва : Айрис-пресс, 2004. 464 с.

15. Хьелл Л., Зиглер. Д. Теории личности. Санкт-Петербург : Питер Ком, 1999. 688 с.

16. Чабан О. С., Хаустова О. О. Психічне здоров'я в період пандемії COVID-19 (особливості психологічної кризи, тривоги, страху та тривожних розладів). Неŭро News. 2020. № 3. С. $26-36$.

17. Ялтонский В. М. Копинг-поведение здоровых и больных наркоманией : дис. ... д-ра мед. наук : 14.00.45. Санкт-Петербург, 1995. 398 с.

18. Lazarus, R.S., Folkman S. Stress, appraisal, and coping. New York : Springer Pub. Co., 1984. 456 p.

19. Folkman, S., Lazarus, R.S. Manual for the Ways of Coping Questionnaire. Palo Alto, CA: Consulting Psychologists Press, $1988.52 \mathrm{p}$.

20. Slavich, G.M. \& Irwin, M. R. From stress to inflammation and major depressive disorder: a social signal transduction theory of depression. Psychol. Bull. 2014. 140, 774-815.

21. Ge, L., Yap, C.W., Ong, R. \& Heng, B. H. Social isolation, loneliness and their relationships with depressive symptoms: a population-based study. PLoS ONE. 2017. № 12, e0182145.

22. Matthews, T. et al. Social isolation, loneliness and depression in young adulthood: a behavioural genetic analysis. Soc. Psychiatry Psychiatr. Epidemiol. 2016. № 51, 339-348.

23. Santini, Z.I. et al. Social disconnectedness, perceived isolation, and symptoms of depression and anxiety among older Americans (NSHAP): a longitudinal mediation analysis. Lancet Public Health 5, e62-e70 (2020).

24. Xiang, Y.-T. et al. Timely mental health care for the 2019 novel coronavirus outbreak is urgently needed. Lancet Psychiatry. 2020. № 7, 228-229.

25. Barzilay, R. et al. Resilience, COVID-19-related stress, anxiety and depression during the pandemic in a large population enriched for healthcare providers. Transl. Psychiatry. 2020. № 10, 291.

26. Mertens, G., Gerritsen, L., Duijndam, S., Salemink, E. \& Engelhard, I. M. Fear of the coronavirus (COVID-19): Predictors in an online study conducted in March 2020. J. Anxiety Disord. 2020. № 74, 102258. 